\title{
UJI KADAR GAS METAN SAMPAH ORGANIK PASAR TARUMANEGARA MENGGUNAKAN RANCANG BANGUN TONG SAMPAH LISTRIK TERINTEGRASI SENSOR SEBAGAI POTENSI SUMBER ENERGI ALTERNATIF
}

\author{
ALHARA YUWANDA ${ }^{1)}$, BUANA SUHURDIN, \& DEDI RUTAMA \\ 1)Jurusan Teknik Elektro, Sekolah Tinggi Teknologi Jakarta \\ Email: alhara@sttj.ac.id ${ }^{()}$
}

\begin{abstract}
Energy can be produced from several sources collected and harvested by conversion to electricity. One of the media is electrolysis of organic waste. But an update is needed to create a system with integrated computers. Organic waste processing machines that are integrated with temperature and humidity sensors are developed because of the need for alternative solutions. DHT 11 and MQ4 Sensors are used to test humidity and methane. The graph shows an increase and decrease in the gas produced. The results of the optimal peak graph produced on the 8th day were $2650 \mathrm{ppm}$ with a barrel volume of onegallon digester of 19 liters. This is in accordance with the temperature and humidity produced, namely on days 7 th. These results can be the basis of farmers who produce methane gas and the method of this prototype to evaluate the methane gas produced.
\end{abstract}

Keywords: Digester, Sensor, Methane.

\begin{abstract}
ABSTRAK
Energi dapat dihasilkan dari beberapa sumber yang dikumpulkan dan dipanen dengan konversi menjadi listrik. Salah satu media nya adalah elektrolisis dari limbah organik. Tetapi diperlukan pebaharuan untuk membuat sistem dengan terintegrasi komputer. Mesin pengolah limbah organik yang terintegrasi dengan sensor suhu dan kelembaban ini dikembangkan karena kebutuhan solusi alternative. Digunakan Sensor DHT 11dan Sensor MQ4 untuk menguji kelembaban dan metan. Grafik menunjukan peningkatan dan penurunan gas yang dihasilkan. Hasil dari grafik puncak optimal yang dihasilkan.pada hari ke 8 yaitu sebesar $2650 \mathrm{ppm}$ dengan volume tong digester satu galon sebanyak 19 Liter. Hal tersebut sesuai dengan suhu dan kelembapan yang dihasilkan yaitu pada hari ke 8 dan 9 . Hasil ini dapat menjadi dasar petani yang memproduksi gas metan dan metode dari prototype ini untuk mengevaluasi gas metan yang dihasilkan.
\end{abstract}

Kata Kunci: Tong Sampah, Sensor, Metana.

\section{PENDAHULUAN}

Masyarakat dunia pada saat ini, dituntut harus mempunyai solusi dalam mengatasi permasalahan krisis energi. Krisis energi ini diakibatkan oleh maraknya penggunaan energi non terbarukan yang jika terus dipakai terus menerus akan semakin menipis. Berdasar- kan publikasi ESDM tahun 2016 tentang gambaran umum penyediaan listrik nasional tahun 2015, penggunaan energi untuk membangkitkan listrik di Indonesia masih didominasi oleh batubara sebesar 50\%, gas sebesar $25 \%$, minyak bumi sebesar $14 \%$, dan energi baru terbarukan 11\% (Kementrian, 2016). 
Data tersebut menunjukan penggunaan energi batu bara masih mendominasi dibandingkan energi baru terbarukan. Kementerian Kehutanan Direktorat Jenderal Planologi Kehutanan mengindikasi adanya 42 perusahaan tambang batubara di Provinsi Bengkulu dalam kawasan hutan konservasi dan hutan lindung di wilayah tersebut (Kementrian, 2016). Padahal hutan memiliki fungsi vital bagi kelangsungan ekosistem di bumi. Didalam hutan, kumpulan pohon-pohon akan menghasilkan limbah berupa daun-daun kering. Limbah pepohonan tersebut pada umumya dimanfaatkan sebagai substrat pembentuk kompos organik. Kompos organik tersebut merupakan hasil degredasi bahan organik oleh bakteri. Sistem degredasi oleh bakteri tersebut menghasilkan gas metan yang dapat dimanfaatkan untuk membuat sumber energi alternatif yang disebut Microbial Fuel Cell (Januarita, 2015).

Gas metana (CH4) yang merupakan komponen utama biogas dapat menjadi bahan bakar yang berguna karena mempunyai nilai kalor yang cukup tinggi, yaitu sekitar 4800$6700 \mathrm{kkal} / \mathrm{m}^{3}$, sedangkan gas metana murni mengandung energi $8900 \mathrm{kkal} / \mathrm{m}^{3}$ (Damanhuri dkk., 2008). Karena nilai kalor yang cukup tinggi itulah biogas dapat dipergunakan untuk keperluan penerangan, memasak, menggerakkan mesin dan sebagainya. Sudah banyak petani yang memanfaatkan gas metan sebagai sumber energy alternatif. Kekurangannya mereka tidak mengetahui jumlah gas yang dihasilkan.Mesin pengolah limbah organik yang terintegrasi dengan sensor suhu dan kelembaban ini dikembangkan karena kebutuhan solusi alternatif dari masalah pengomposan tersebut. Mesin ini menggunakan sistem kerja pencacah dan pengaduk yang dijadikan satu, sehingga tidak dibutuhkan lagi ruang yang luas. Sistem kerja sensor dan otomasi memungkinkan pengolahan kompos dilakukan secara otomatis dan akurat menurut suhu normal saat pengomposan. Oleh karena itu, dibutuhkan penelitian dan pembuatan alat konversi energi listrik berbasis lingkungan yang terintegrasi dengan sensor seperti suhu, kelembapan, dan gas metan yang dihasilkan (Muhammad, 2011).

\section{MATERIAL DAN METODOLOGI PENELITIAN}

1. Alat dan Bahan

Guna medapat tujuan yang diinginkan penelitian ini: Multimeter, Gergaji Besi, Bor Listrik, Tang Kombinasi, Ember Tertutup, Solder Listrik, Sarung Tangan PLastik, Sampah Pasar, Lem Epoksi, Wadah Tertutup, Towe Penyangga, Karbon Aktif, Alumunium Mesh, Toolbox, Capit Buaya, Lem Tembak, Selang, Lakban, Mikroprosesor, Sensor Suhu, Sensor kelembapan, Sensor gas metana, Lem batang, Sensor EM 4, Sensor DHT 11, Biodegester. Digunakan Galon dengan volume $19 \mathrm{~L}$.

\section{Desain Alat}

Tahap perancangan alat ukur Methane Standard Index (MSI). Tahap pembuatan alat ukur Methane Standard Index menggunakan basis mikrokontroller Arduino. Tahap pembuatan dimulai dengan perakitan komponenkomponen sensor MQ-4, DHT-11, DFR0026 dan GPS Shield ke modul Arduino board. Kemudian tahapan pemrograman bahasa arduino yang kemudian di insert dan ditanam ke mikrokontroller dengan aplikasi uploader IDE arduino. Data yang terukur oleh mikrokontroller adalah temperature dan Methane Standard Index (MSI) dan analisis hasil pengukuran.

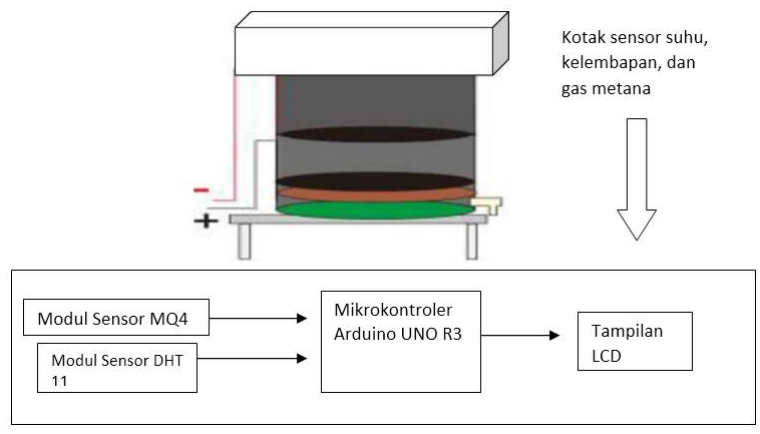

Gambar 1. Desain Prototype Rangkaian Alat dan Sensor 


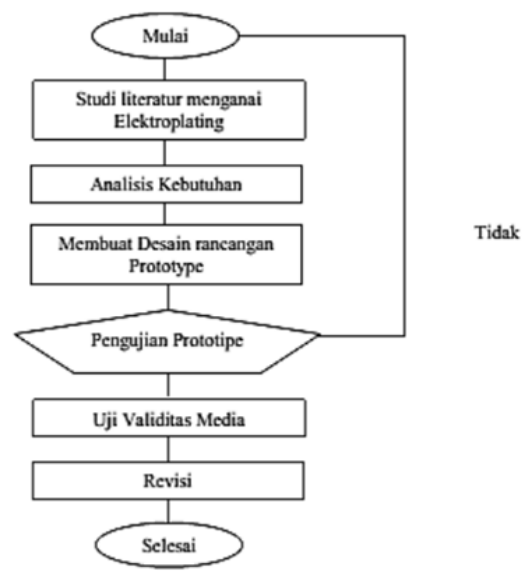

Gambar 2. Bagan Kerja Penelitian

\section{Persiapan Sampah Organik}

Sampah dicacah dalam satu mesin blender sehingga menjadi halus. Berdasarkan teori hasil cacahan harus memenuhi standar, yaitu berkisar antara 25-75 mm (Tchnobanoglous, 2003). Substrat dasar dihancurkan terlebih dahulu dengan diremas-remas dengan dicampur dengan air agar lebih mudah hancur sehingga substrat dalam digester akan homogen. Selanjutnya diberi gula dan diberi biodigester. Pengisian substrat ke dalam digester dilakukan satu kali tidak dilakukan secara continue. Sampah hasil cacahan yang digunakan dengan volume 7L. Digester diletakkan pada suhu lingkungan selama 1 sampai 20 hari. Selama pembuatan biogas, dilakukan pengamatan volume gas yang terbentuk setiap pukul 10.00 WIB, selain volume dilakukan pula pengukuran sampel gas untuk analisis kadar metan. Pengukuran dilakukan pada hari ke 1 dan diluang sampai hari ke 20 (Amanah, 2012).

\section{Teknik Pengumpulan dan Analisis Data}

Teknik pengumpulan data pada penelitian ini adalah dengan mengukur hasil pengkajian dari segi teknologi meliputi daya yang dihasilkan, emisi gas buangan, keunggulan dan tingkat keamanan bagi operator. Sedangkan segi. Pada penelitian ini ditetapkan variabel yang diukur yaitu: data gas metana yang di terima setelah deteksi sensor dari tong sampah, data kelembapan pada sampah yang dikorelasikan dengan tegangan, data tegangan yang dihasilkan dari pengubahan gas metana. Gas yang diukur dalam satuan ppm atau bagian per Sejuta Bagian\| adalah satuan konsentrasi yang sering dipergunakan dalam Kimia Analisis (Asmarawati, 2015). Satuan ini sering digunakan untuk menunjukkan kandungan suatu senyawa. Seperti halnya namanya yaitu ppm, maka konsentrasinya merupakan perbandingan antara berapa bagian senyawa dalam satu juta bagian suatu system atau lebih mudahnya ppm adalah satuan konsentrasi yang dinyatakan dalam satuan $\mathrm{mg} / \mathrm{Kg}$ karena $1 \mathrm{Kg}=1.000 .000 \mathrm{mg}$ (Damanhuri, 2016).

$$
\boldsymbol{p p m}=\frac{\text { Jumlah bagian }}{\text { Satu juta bagian sistem }}
$$

\section{Uji Nyala Api}

Uji nyala dilakukan menggunakan burner yang terbuat dari bekas tempat permen berbentuk bulat, pada tiap sisinya diberi lubang sebagai tempat api keluar. Uji nyala dilakukan setelah gas mulai terproduksi, hal ini bertujuan untuk mengetahui biogas yang dihasilkan apakah mengandung metan atau tidak, sehingga nanti bisa digunakan sebagai bahan pengganti minyak tanah atau elpiji. Gas yang telah ditampung pada balon udara lalu disambungkan pada burner menggunakan selang plastik, kemudian ujung selang tersebut isulutkan pada sumber api. Hal ini bertujuan untuk mengetahui apakah terdapat kandungan gas metan dalam proses fermentasi biogas tersebut. Nyala api merupakan salah satu indikator berhasil atau tidaknya proses fermentasi pada biogas tersebut. Hasil akhir yangdiharapkan dari proses biogas ialah menghasilkan nyala api yang biru, sehingga apabila digunakan dalam kehidupan seharihari akan terasa manfaat bagi penggunanya (Asmarawati, 2015).

\section{HASIL DAN PEMBAHASAN}

1. Uji Kelembapan dan Temperatur Lingkungan

DHT11 adalah sensor Temperature \& Humidity yang memiliki output sinyal digital yang telah terkalibrasi.

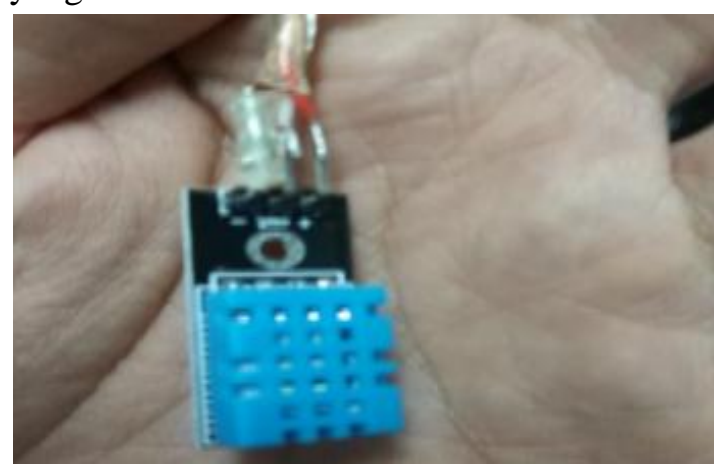

Gambar 3 Hasil Rancangan Sensor DHT 11 
Menggunakan teknik Digital Signal Acqusition dan teknologi penginderaan suhu dan kelembaban, sensor ini memiliki keandalan tinggi dan stabilitas jangka panjang yang baik. Sensor ini mencakup komponen pengukuran kelembaban resistif dan komponen pengukuran suhu. Kondisi lingkungan saat terdeteksi gas metan sebagai berikut:

Tabel 1 Hasil Pengujian Kelembapan Pada Tong Digester

\begin{tabular}{lll}
\hline Item & Humadity & Package \\
\hline DHT-11 & $95 \mathrm{RH}$ & 4 Pin Single Row \\
\hline
\end{tabular}

DHT11 adalah sensor Temperature \& Humidity yang memiliki output sinyal digital yang telah terkalibrasi. Menggunakan teknik Digital Signal Acqusition dan teknologi penginderaan suhu dan kelembaban, sensor ini memiliki keandalan tinggi dan stabilitas jangka panjang yang baik. Sensor ini mencakup komponen pengukuran kelembaban resistif dan komponen pengukuran suhu NTC yang terhubung pada mikrokontroller 8 bit sehingga menawarkan kualitas yang baik, respon cepat dan kemampuan anti gangguan. Sensor ini digunakan untuk mendapatkan kondisi optimum pada reaksi anaerob bakteri didalam tong. Data tersebut menjadi dasar untuk pengolahan dan produksi gas metan dalam skala yang besar.

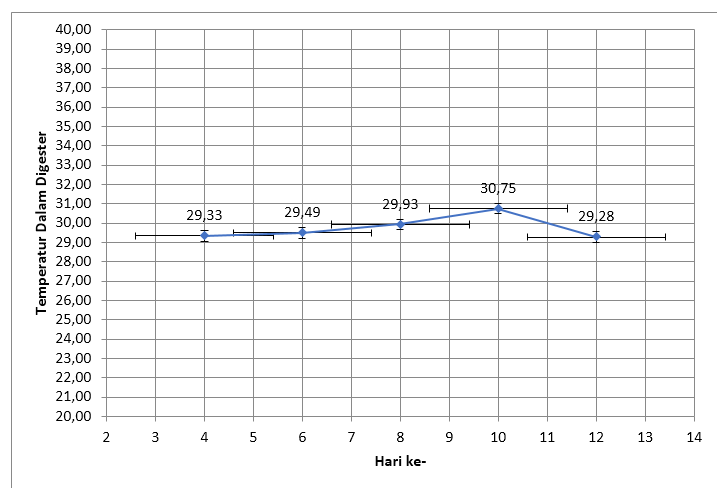

Gambar 2. Grafik Perubahan Temperatur Pada Tong Digester

Berdasarkan data diatas dapat dilihat kondisi grafik perubahan temperature yang meningkat dan menurun. Hal tersebut akibat pengaruh dan reaksi gas metan yang dihasilkan. Temperature phased anaerobic digestion (TPAD) menghasilkan gas metana pada produksi gas metana antara suhu $20{ }^{\circ} \mathrm{C}$ sampai $40{ }^{\circ} \mathrm{C}$. Kondisi optimum pada hari ke 9 sampai hari ke 11. Kondisi temperature optimum lingkungan pada tong tercatat $30,75^{\circ} \mathrm{C}$. Sistem pengkondisi suhu substrat pada subreaktor metanogenesis bekerja dengan cara mengatur suhu air yang terdapat di sekeliling subreaktor metanogenesis. Subreaktor metanogenesis dilengkapi dengan selimut air dan peredam panas, sehingga proses pertukaran panas antara air yang dikondisikan di selimut air dan substrat di dalam subreaktor dapat menjadikan suhu substrat terkondisikan. Dalam proses pengkondisian dibuatlah beberapa aksi sistem yang terkarakterisasi sehingga dapat mengakomodasi target capaian suhu dari gangguan lingkungan bahkan internal proses itu sendiri.

\section{Rancang dan Uji Gas Metan dengan Sensor MQ4}

Dengan menggunakan rangkaian hasil rancangan sistem senor seperti pada gambar, dilakukan pengujian. Pengujian sensor terhadap gas MQ4.

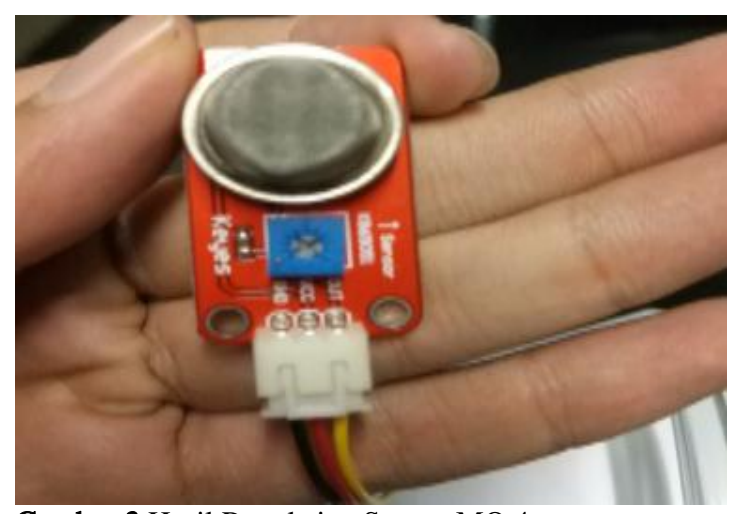

Gambar 3 Hasil Rangkaian Sensor MQ 4

Teknologi ini memanfaatkan mikroorganisme yang tersedia di alam untuk merombak dan mengolah berbagai limbah organik yang ditempatkan pada ruang kedap udara (anaerob) (Imanudin dkk,. 2014). Hasil proses perombakan tersebut dapat menghasilkan pupuk organik cair dan padat bermutu berupa gas yang terdiri dari gas metana $(\mathrm{CH} 4)$ dan gas karbon dioksida (CO2). Pada umumnya, biogas terdiri atas gas metana sekitar 55$80 \%$, dimana gas metana diproduksi dari kotoran hewan yang mengandung energi 4.800-6.700 Kkal/m3, sedangkan gas metana murni mengandung energi $8.900 \mathrm{Kcal} / \mathrm{m} 3$. Produksi gas metan sangat tergantung oleh rasio $\mathrm{C} / \mathrm{N}$ dari substrat. Menurut Hartono (2009) rentang rasio $\mathrm{C} / \mathrm{N}$ antara 25-30 merupakan rentang optimum untuk proses penguraian anaerob. Jika rasio $\mathrm{C} / \mathrm{N}$ terlalu 
tinggi, maka nitrogen akan terkonsumsi sangat cepat oleh bakteri-bakteri metanogen untuk memenuhi kebutuhan protein dan tidak akan lagi bereaksi dengan sisa karbonnya (Januarit dkk., 2015).

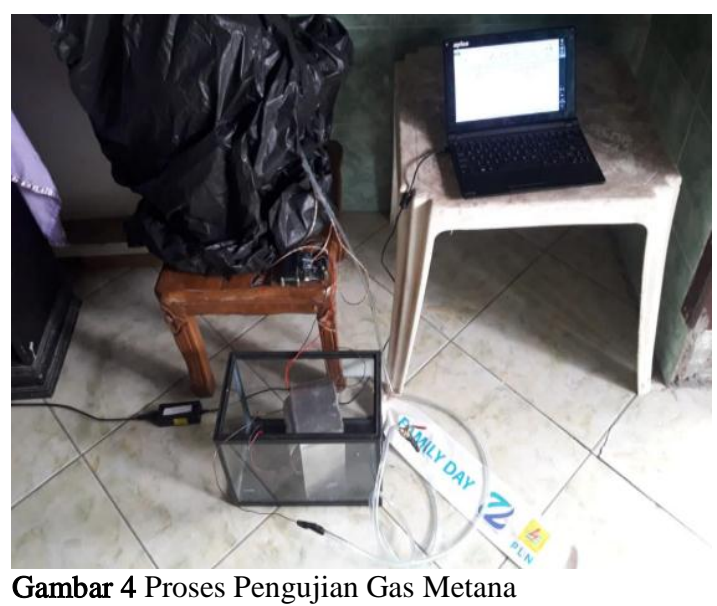

Berdasarkan literature biodigester secara umum dapat dioperasikan pada range temperatur: a) psikrofilik di bawah $28^{\circ} \mathrm{C}$; b) temperatur medium mesofilik pada $29^{\circ} \mathrm{C}-45^{\circ} \mathrm{C}$; c) Termofilik pada $50^{\circ} \mathrm{C}-56^{\circ} \mathrm{C}$. Kondisi pengujian berada di kondisi tertutup (anaerob) dan ditutup dengan kain hitam untuk menjaga kelembapan dam melindungi bakteri dari cahaya matahari. Temperatur mempengaruhi proses pertumbuhan dan perkembangbiakan dari bakteri-bakteri yang terlibat dalam proses produksi biogas secara anaerobik. Pencernaan anaerobik dapat berlangsung pada suhu $5^{\circ} \mathrm{C}$ sampai dengan $55^{\circ} \mathrm{C}$. Temperatur optimum untuk proses produksi biogas $30^{\circ} \mathrm{C}$ sampai dengan $37^{\circ} \mathrm{C}$. Produksi biogas dari proses pencernaan anaerobik bergantung pada temperatur dan jumlah asam yang terbentuk (Nasruallah, 2012).

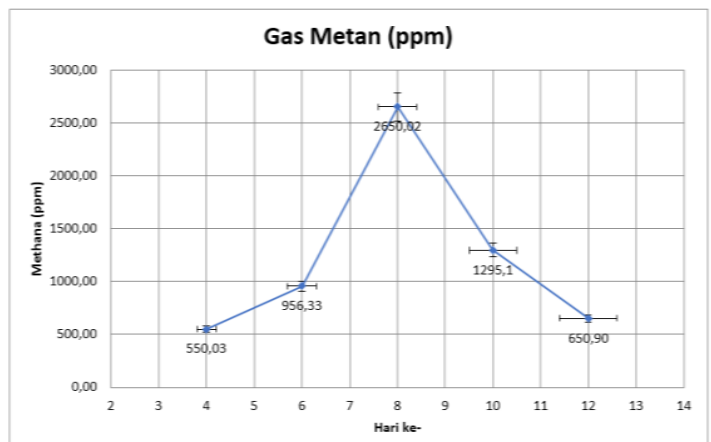

Gambar 5. Grafik Hasil Gas Metan Hasil Pengujian Gas Metan

Gambar 5 menunjukankadar gas metana yang dihasilkan dari fermentasi 7L sampaha pasar pada prototype biodigester. Gambar 5 menunjukan grafik yang meningkat dan terjadi penurunan. Sehingga dari grafik tersebut menunjukan kondisi optimum gas metana yang dihasilkan pada hari ke 7 sampai ke 9 . Data tersebut dapat dijadikan acuan untuk mengetahui dan meningkatkan produksi jika ada kontrol yang lebih baik dalam reaktor biogas dalam jumlah besar. Selanjutnya dilakuan uji kualitatif untuk mengetahui apakah gas yang terbentuk mengandung gas metan, dilakukan uji nyala dengan menampung gas yang dihasilkan pada sebuah balon. Hasil yang diperoleh menunjukkan gas yang dihasilkan mengandung gas metan sebab nyala yang ditimbulkan berwarna biru. Nyala gas warna yang paling besar di hari ke 8 sesuai dengan kondisi grafik pada Gambar 5. Pada umumnya apabila gas metana ini dibakar maka akan berwarna biru dan menghasilkan banyak energi panas ( Yenie, 2008).

\section{KESIMPULAN}

Hasil penelitian menunjukkan bahwa sistem pemantauan berbasis mikrokontroler Arduino yang dirancang dapat bekerja dengan baik dalam mengukur gas metana dari sampah organic pasaar.. Sistem yang dirancang juga mampu mengukur konsentrasi biogas yang terbentuk. Kedua bacaan sensor tersebut dapat diolah oleh mikrokontroler dan ditampilkan pada LCD.

\section{DAFTAR PUSTAKA}

Amanah, Farisatul. 2012. Pengaruh Pengadukan dan Komposisi Bahan Kompos Terhaddap Kualitas Kompos Campuran Lumpur Tinja. Skripsi Sarjana pada FT UI: tidak diterbitkan

Asmarawati, Dwi. 2015. Pengembangan Modul Pembelajaran Kimia Pada Materi Koloid Dengan Pendekatan Saintifik Melalui Penerapan Professional Learning Community [Skripsi]. Jakarta: Fakultas Matematika dan Ilmu Pengetahuan Alam, Universitas Negeri Jakarta.

Damanhuri, Enri dan Tri Padmi. 2008. Diktat Kuliah Pengelolaan Sampah TL- 3104. Institut Teknologi Bandung.

Gupta, J.K. dan Khurmi R.S. 2015. A Textbook of Machine Design. New Delhi: Eurasia Publishing House. 
Imaduddin, Muhamad, dkk.2014. Pemanfaatan sampah sayur pasar dalam produksi listrik melalui microbial fuel cells. Diakses pada http://jurnal.unimus.ac.id/index.php/ME/ article/view/1368 pada tanggal 29-032017

Januarita, Rizky, Dkk. 2015. MFCS 2 IN 1: Microbial Fuel Cells Pengolah Air Limbah dan Penghasil Listrik (Alternati: Limbah Isi Rumen Sapi Dengan Pengaruh Variasi COD dan $\mathrm{PH}$ ) diakses pada eprints.undip.ac.id/45811/1/Rev_Rizki_J anuarita_-

_MICROBIAL_FUEL_CELLS.pdf tanggal 29-03-2017

Kementrian ESDM. 2016. Percepatan Akses Energi Di Indonesia: Opsi Peluang dan Tantangannya. Jakarta; Kementrian ESDM Ester Kristin. 2012. Produksi Energi Listrik Melalui Microbial Fuel Cell Me Nggunkan Limbah Industri Tempe.

Diakses http://lib.ui.ac.id/file?file=digital/ 124980
-R040854- Performa\%20selLiteratur.pdf pada tanggal 29-03-2017

Kementrian Negara Lingkungan Hidup Republik Indonesia. 2008. Statistik Persampahan Indonesia.

Muhammad Fikri. 2011. Microbial Fuel Cell. Diakses pada https://www.itb.ac.id/news/read/3130/ho $\mathrm{me} /$ microbial-fuel-cellenergilistrik-

alternatif-dari-bakteri tanggal 29-0320172 Sularso dan, Suga, Kiyokatsu, 2008. Dasar Perencanaan dan Pemilihan Elemen Mesin. Jakarta: PT. Pradnya Paramita

Nasrullah. 2012. Disain Portabel Composter Sebagai Solusi Alternatif Sampah Organik Rumah Tangga. Jurnal Teknik Lingkungan UNAND. IX (1): 50- 58. Padang: Politeknik Negeri Padang.

Yenie, Elvie. 2008. Kelembaban Bahan dan Suhu Kompos Sebagai Parameter yang Mempengaruhi Proses Pengomposan Pada Unit Pengomposan Rumbai. Jurnal Sains dan Teknologi. VII (2): 58 - 61. Pekanbaru: Universitas Riau. 